\title{
THE EFFECT OF PROFITABILITY ON CAPITAL STRUCTURE IN THE MANUFACTURING COMPANIES SUBSECTOR METALS LISTED IN INDONESIA STOCK EXCHANGE (IDX) YEAR 2011-2013
}

by:

Amelia Fitriani I.P

Imas Purnamasari

\begin{abstract}
This study aims to determine the effect of profitability on the capital structure of the Manufacturing Companies subsector Metals are Listed in Indonesia Stock Exchange in 2011-2013, in this study profitability is measured using the Return on Assets (ROA), and capital structure were measured using Debt to Equity Ratio (DER). The method used is descriptive method verification. The data collection techniques used is a method of documentation. Data in the form of financial statements obtained from the official website of Indonesia Stock Exchange 2011-2013. With a total sample of 10 Metals Companies listed on the BEI for three periods of study in order to get 30 data observan. Statistical analysis used is simple linear regression analysis, which is preceded by a test for normality and linearity as a prerequisite regression test then testing the significance of regression ( $F$ test) and regression coefficient significance test (t test). Based on the results of data processing, the known value of ROA decreased, while DER increased. Based on the statistical test result that profitability does not affect the capital structure.
\end{abstract}

Keywords: Profitability, Capital Structure. 


\section{Pendahuluan}

Semakin maju dan berkembangnya perekonomian dan teknologi yang terjadi dewasa ini, menuntut perusahaan untuk terus mengembangkan usahanya agar tetap dapat bersaing. Dengan semakin berkembangnya perekonomian, maka semakin banyak pula perusahaan yang berkembang. Hal ini menyebabkan persaingan yang ketat dan setiap perusahaan berlomba untuk memberikan pelayanan yang lebih baik lagi.

Secara umum tujuan perusahaan yaitu untuk meningkatkan kesejahteraan pihak-pihak yang berkaitan dengan perusahaan dengan memaksimumkan laba. Berhasil atau tidaknya suatu perusahaan dalam mencapai tujuannya biasanya ditinjau dari kinerja perusahaan. Perusahaan dengan kinerja yang baik memiliki pertimbangan yang baik dalam melakukan pembelanjaan. Pembelanjaan perusahaan, pengaturan struktur keuangan serta struktur modal perusahaan memerlukan perencanaan dan analisa yang benar-benar harus dipertimbangkan agar menghasilkan perimbangan yang optimal antara jumlah utang dan modal sendiri.

$\begin{array}{llr} & \text { Riyanto }(2010: 22) & \text { menyatakan } \\ \text { bahwa "Struktur modal } & \text { adalah } \\ \text { pembelanjaan permanen dimana } \\ \text { mencerminkan perimbangan atau }\end{array}$
perbandingan antara utang jangka panjang dengan modal sendiri". Perimbangan ini harus berdasarkan standar struktur modal yang baik yaitu jumlah utang jangka panjang tidak melebihi modal sendiri. Struktur modal perusahaan dapat diukur dengan Debt To Equity Ratio, rasio ini menggambarkan sejauh mana modal pemilik dapat menutupi utang-utang kepada pihak luar. Debt To Equity Ratio menurut Sawir (2005:13) "merupakan rasio yang menggambarkan hutang dan modal dalam pendanaan perusahaan dan menunjukkan kemampuan modal sendiri perusahaan tersebut untuk memenuhi kewajibannya". Perbandingan struktur modal yang optimal menunjukkan jumlah modal asing yang tidak lebih besar dari modal sendiri atau disebutkan dalam skala perbandingan 50:50.

Berikut merupakan grafik rata-rata DER Perusahaan Manufaktur Subsektor Logam dan Sejenisnya yang terdaftar di Bursa Efek Indonesia periode 2011-2013:

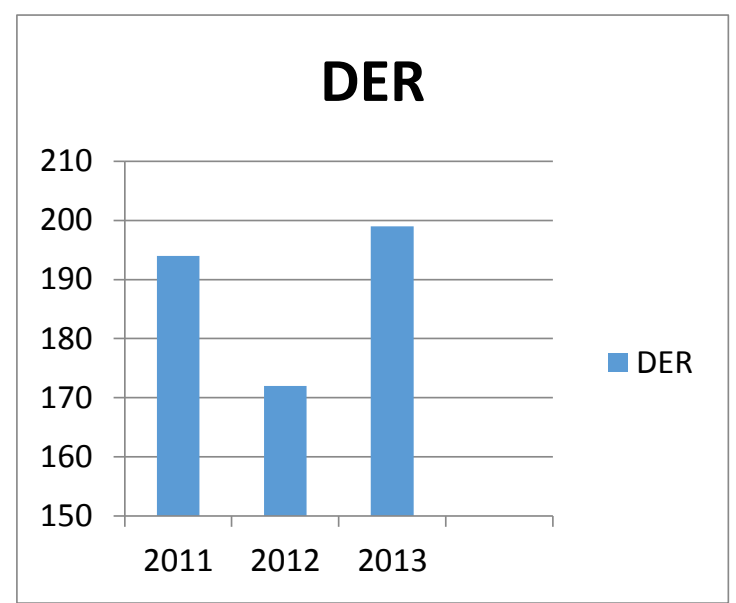

Berdasarkan grafik tersebut, terlihat bahwa rata-rata DER Perusahaan Manufaktur Subsektor Logam dan Sejenisnya sebesar 194\% di tahun 2011, $174 \%$ di tahun 2012 , dan $199 \%$ di tahun 2013. Hal ini menunjukkan bahwa struktur modal relatif kurang optimal. Keadaan struktur modal yang kurang optimal karena nilai DER melebihi 100\%. Hal ini menunjukkan bahwa perusahaan lebih banyak menggunakan utang.

Perusahaan tidak dapat membiarkan keadaan struktur modal ini karena akan merugikan perusahaan bahkan bisa mengalami kebangkrutan, karena semakin besar DER semakin besar resiko perusahaan. Sejalan dengan tradeoff theory yang menyatakan bahwa "semakin tingginya hutang, akan semakin tinggi kemungkinan (probabilitas) kebangkrutan".

Dalam keberlangsungan usahanya, perusahaan memerlukan dana yang besar untuk terus dapat meningkatkan kualitasnya. Jika modal sendiri tidak dapat menutupi kebutuhan dana tersebut, keputusan yang dapat dilakukan oleh perusahaan yaitu dengan mencari modal asing yaitu dana pinjaman. Akan tetapi, kreditur tidak semudah itu dapat memberikan dananya pada perusahaan. Salah satu hal penting yang diperhatikan kreditur pada perusahaan adalah bagaimana keadaan financial perusahaan tersebut. Tingkat profitabilitas perusahaanlah yang bisa menjadi jaminan bagi para kreditur.

Salah satu cara untuk mengoptimalkan struktur modal yaitu dengan meningkatkan tingkat profitabilitas perusahaan. Menurut Harahap (2008:304) "profitabilitas menggambarkan kemampuan perusahaan mendapatkan laba melalui semua kemampuan dan sumber yang ada 
seperti kegiatan penjualan, kas, modal, jumlah karyawan, jumlah cabang, dan sebagainya". Profitabilitas dapat mengukur seberapa baik kemampuan perusahaan menghasilkan laba dan bagaimana kemudian laba tersebut dapat menutupi kewajiban perusahaan. Semakin besar laba yang dihasilkan, maka semakin besar kemungkinan perusahaan memiliki jumlah modal sendiri yang besar serta semakin besar pula kemampuan perusahaan dalam menutupi kewajiban-kewajibannya.

Seperti yang dikatakan Brigham dan Houston (2001:40) "Perusahaan dengan tingkat yang tinggi atas investasi menggunakan utang yang relatif kecil. Laba ditahannya yang tinggi sudah membiayai sebagian besar kebutuhan pendanaan". Jika modal yang dimiliki perusahaan sudah mencukupi untuk pendanaan perusahaan, perusahaan akan mengurangi jumlah penggunaan hutangnya.

Berdasarkan teori yang dikemukakan di atas, profitabilitas merupakan salah satu faktor yang dapat mempengaruhi struktur modal. Struktur modal yang baik dapat dihasilkan dengan meningkatkan profitabilitas perusahaan. Meningkatknya profitabilitas perusahaan menunjukkan bahwa perusahaan mampu memaksimalkan keseluruhan kemampuannya dalam menghasilkan laba. Dan laba yang tinggi merupakan salah satu langkah perusahaan untuk mencapai tujuan perusahaan yaitu menyejahterakan dan meningkatkan nilai perusahaan. Oleh karena itu, perusahaan harus dapat memaksimalkan kemampuannya dari segala potensi yang dimiliki untuk dapat meningkatkan tingkat profitabilitas perusahaan karena profitabilitas merupakan hal penting bagi perusahaan yang kemudian akan mempengaruhi besarnya modal sendiri perusahaan. Perusahaan yang memiliki modal sendiri yang mencukupi, dapat mengurangi risiko untuk menutupi kewajiban pada kreditur dan mengurangi ketergantungan dana pada pihak luar.

Berdasarkan fenomena yang telah dijelaskan sebelumnya, peneliti tertarik untuk meneliti yang berkaitan dengan hal tersebut dengan mengambil judul "Pengaruh Profitabilitas Terhadap Struktur Modal Pada Perusahaan Manufaktur Subsektor Logam dan Sejenisnya Yang Terdaftar di Bursa Efek Indonesia Tahun 2011-2013".
Teori yang digunakan untuk melakukan penelitian ini adalah sebagai berikut:

\section{Kinerja Keuangan}

Menurut Sutrisno (2009:53) "Kinerja keuangan merupakan prestasi yang diciptakan perusahaan dalam suatu periode tertentu yang mencerminkan tingkat kesehatan perusahaan tersebut". Menurut Horne (2007:9) mengatakan bahwa "Kinerja keuangan adalah merupakan ukuran prestasi perusahaan maka keuntungan adalah merupakan salah satu alat yang digunakan oleh para manajer". Menurut Munawir (2008:30), "Kinerja keuangan perusahaan merupakan satu diantara dasar penilaian mengenai kondisi keuangan perusahaan yang dilakukan berdasarkan analisa terhadap rasio keuangan perusahaan".

Berdasarkan pengertian tersebut kinerja keuangan menunjukkan gambaran pencapaian atau prestasi perusahaan dalam menjalankan kegiatannya yang dapat dilihat pada laporan keuangan perusahaan tersebut dalam periode tertentu dengan menggunakan analisis rasio keuangan.

\section{Analisis Laporan Keuangan}

Mengenai analisis laporan keuangan menurut Harahap (2008:1) menyatakan bahwa "Menganalisis laporan keuangan berarti menggali lebih banyak informasi yang dikandung suatu laporan keuangan". Sedangkan menurut Munawir $(2008 ; 35)$ "Analisis laporan keuangan adalah analisis laporan keuangan yang terdiri dari penelaahan atau mempelajari daripada hubungan dan tendensi atau kecenderungan (trend) untuk menentukan posisi keuangan dan hasil operasi serta perkembangan perusahaan yang bersangkutan".

Berdasarkan pengertian di atas, dapat disimpulkan bahwa untuk menilai kondisi keuangan dilakukan dengan menganalisis laporan keuangan dengan cara menggali informasi laporan keuangan lebih dalam. Salah satu teknik dalam menganalisis laporan keuangan adalah dengan analisis rasio keuangan.

\section{Analisis Rasio Keuangan}

"Rasio keuangan adalah angka yang diperoleh dari hasil perbandingan dari satu pos laporan keuangan dengan pos lainnya yang mempunyai hubungan yang relevan dan signifikan (berarti)" (Harahap, 2008:297). 
Dengan menganalisis rasio keuangan dapat dicari informasi kemudian membandingkan dari rasio satu dengan yang lainnya yang setelah itu dapat dilihat kondisi keuangan perusahaan. Analisis rasio dapat digunakan bagi manajemen perusahaan untuk merencanakan dan mengevaluasi hasil kerja, selain itu bagi pihak eksternal atau kreditor dapat digunakan untuk memperkirakan potensi resiko atas kemampuan perusahaan dalam mengembalikan utang.

\section{Profitabilitas}

Menurut Irawati (2005:58) "profitabilitas adalah rasio yang digunakan untuk mengukur efisiensi pengunaan aktiva perusahaan". Sartono (2008:122) mengemukakan bahwa "profitabilitas adalah kemampuan perusahaan dalam memperoleh laba dalam hubungannya dalam penjualan, total aktiva maupun modal sendiri". Sedangkan Harmono (2011:109) menyatakan "analisis profitabilitas menggambarkan kinerja fundamental perusahaan ditinjau dari tingkat efisiensi dan efektivitas operasi perusahaan dalam memperoleh laba".

Berdasarkan pengertian tersebut, profitabilitas merupakan ukuran yang digunakan untuk mengetahui kemampuan perusahaan mendapatkan laba melalui hasil akhir dari sebuah kebijakan dan keputusan keuangan berupa semua kemampuan dan sumber yang ada seperti kegiatan penjualan, total aktiva, kas, modal, jumlah karyawan, jumlah cabang, dan sebagainya.

\section{Jenis Profitabilitas}

Riyanto (2010:36) menyatakan bahwa ada dua cara penilaian profitabilitas, yaitu:

\section{a. Profitabilitas Ekonomi}

Profitabilitas ekonomi adalah perbandingan antara laba usaha dengan modal sendiri dan modal asing yang dipergunakan untuk menghasilkan laba tersebut dan dinyatakan dalam persentase. b. Profitabilitas Modal Sendiri

Profitabilitas modal sendiri atau sering disebut juga profitabilitas usaha adalah perbandingan antara laba yang tersedia bagi pemilik modal sendiri dengan jumlah modal sendiri yang menghasilkan laba tersebut.

\section{Rasio Profitabilitas}

Menurut Munawir (2008:246) "rasio profitabilitas adalah rasio yang mengukur efektifitas manajemen secara keseluruhan yang ditunjukkan oleh besar kecilnya keuntungan yang diperoleh dalam hubungannya dengan penjualan dan investasi". Sedangkan menurut Harahap (2008:304) "rasio rentabilitas atau disebut juga profitabilitas menggambarkan kemampuan perusahaan mendapatkan laba melalui semua kemampuan, dan sumber yang ada seperti kegiatan penjualan, kas, modal, jumlah karyawan, jumlah cabang, dan sebagainya".

Beberapa jenis rasio profitabilitas dapat dikemukakan sebagai berikut:

a. Margin Laba (Profit Margin)

b. Asset Turn Over (Return On Asset)

c. Return On Investment (Return On Equity)

d. Return On Total Asset

e. Basic Earning Power

f. Earning Per Share (EPS)

g. Contribution Margin (Gross Margin Ratio)

\section{Return on Asset (ROA)}

Menurut Harahap (2008:305)

"Return on Asset (ROA) menggambarkan perputaran aktiva diukur dari volume penjualan". Sutrisno (2005:226) mengemukakan bahwa "Return On Assets juga sering disebut sebagai rentabilitas ekonomis merupakan ukuran kemampuan perusahaan dalam menghasilkan laba dengan semua aktiva yang dimiliki perusahaan". Sedangkan menurut Munawir (2008:84) "Return on asset (ROA) merefleksikan seberapa banyak perusahaan telah memperoleh hasil atas seluruh sumberdaya keuangan yang ditanamkan perusahaan".

Dari pengertian tersebut, dapat disimpulkan bahwa ROA merupakan salah satu indikator untuk menilai tingkat profitabilitas berdasarkan laba yang diperoleh dari keseluruhan aktiva yang dihasilkan dan seluruh modal yang bekerja di dalamnya.

Adapun rumus untuk menghitung ROA adalah sebagai berikut.

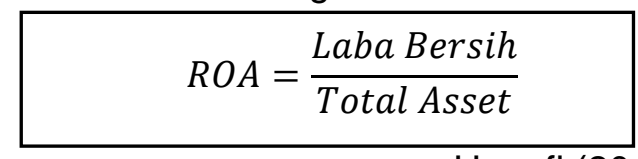

Hanafi (2013:42)

\section{Modal}

Modal menurut Riyanto (2010:17) menyatakan bahwa, "Modal dapat dipandang dari dua sifat yaitu modal klasik dan modal non-physical oriented'. Yang dimaksud dengan modal klasik adalah hasil produksi yang digunakan untuk 
memproduksi lebih lanjut. Sedangkan nonphysical oriented adalah pengertian modal yang ditekankan pada nilai, daya beli atau kekuasaan memakai atau menggunakan hal tersebut yang terkandung dalam barang-barang modal. Pengertian modal menurut Brigham (2001:62) "modal ialah jumlah dari utang jangka panjang, saham preferen, dan ekuitas saham biasa, atau mungkin pos-pos tersebut plus utang jangka pendek yang dikenakan bunga".

Berdasarkan pengertian tersebut, dapat disimpulkan bahwa modal adalah hasil produksi yang digunakan untuk memproduksi lebih lanjut berupa utang jangka panjang, saham preferen, dan ekuitas saham biasa atau pos-pos tersebut ditambah utang jangka pendek yang dikenakan bunga.

Menurut Riyanto (2010:19-22), pembagian jenis modal dapat digolongkan menjadi dua yaitu modal aktif dan modal pasif.

a. Modal Aktif adalah modal yang menunjukkan bentuknya atau dengan kata lain barang-barang yang menggambarkan bentuk dana yang ditanamkan oleh perusahaan. Modal aktif tertera di sebelah debit dari neraca. Jika dilihat dari cara dan lamanya perputaran, modal aktif dapat dibedakan menjadi:

1) Aktiva lancar, yaitu aktiva yang habis dalam satu kali berputar dalam proses produksi dan proses perputarannya adalah dalam jangka waktu yang pendek. (kurang dari satu tahun).

2) Aktiva tetap, yaitu aktiva yang tidak habis pakai dalam proses produksi atau mengalami penyusutannya dalam waktu yanng relatif panjang dan biasanya lebih dari satu tahun. misalnya kendaraan, tanah, bangunan, mesin dan lain-lain.

Ditinjau dari fungsi bekerjanya aktiva dalam perusahaan, modal aktif dapat dibedakan menjadi:

1) Modal kerja (working capital assets), merupakan modal yang sifatnya fleksibel yaitu dapat lebih mudah diperbesar atau diperkecil dan mengalami siklus perputarannya dalam jangka waktu yang pendek.

2) Modal tetap (fixeds capital assets), merupakan modal yang sifatnya tetap atau permanen, artinya perubahaan nilainya tidak mudah untuk dikurangi atau ditambah dengan segera dan proses perputarannya dalam jangka waktu yang panjang. b. Modal Pasif merupakan modal yang menggambarkan sumber-sumber dana yang diperoleh oleh perusahaan atau modal modal yang tertera di sebelah kredit neraca.

Ditinjau dari asalnya modal pasif dapat dibedakan menjadi:

1) Modal sendiri, merupakan modal yang perolehannya berasal dari perusahaan itu sendiri (cadangan, agio, laba ditahan, cadangan) atau modal yang bersumber dari mengambil bagian dari pemilik atau peserta (modal saham, modal peserta).

2) Modal asing, merupakan modal yang berasal dari kreditur atau pihak luar yakni merupakan hutang/pinjaman bagi perusahaan bersangkutan yang harus dikembalikan dalam jangka waktu tertentu. Misalnya: hutang bank.

Jika ditinjau dari lamanya penggunaan dan berdasarkan syarat likuiditas, solvabilitas dan rentabilitas, modal pasif dapat dibagi menjadi:

1) Modal jangka panjang yang ditarik untuk jangka waktu tidak tertentu/terbatas waktunya (dari sudut likuiditas), modal sendiri (dari sudut solvabilitas) dan merupakan modal dengan pendapatan tidak tetap (dari sudut rentabilitas)

2) Modal jangka pendek yang ditarik untuk jangka waktu tertentu/terbatas (dari sudut likuiditas), modal asing (dari sudut solvabilitas) dan merupakan modal dengan pendapatan tetap (dari sudut rentabilitas).

\section{Pengertian Struktur Modal}

$$
\text { Sartono }
$$

mengemukakan bahwa, "Struktur modal merupakan perimbangan jumlah hutang jangka pendek yang bersifat permanen, hutang jangka panjang, saham preferen dan saham biasa". Menurut Ambarwati (2010:1) menyatakan bahwa, "Struktur modal adalah kombinasi atau perimbangan antara hutang dan modal sendiri (saham preferen dan saham biasa) yang digunakan perusahaan untuk merencanakan mendapatkan modal". Sementara itu Sutrisno (2005:273) menyatakan "stuktur modal merupakan perimbangan antara modal asing dengan modal sendiri dimana perusahaan memiliki hutang baik jangka pendek maupun jangka panjang".

Dapat disimpulkan, struktur modal adalah pembelanjaan permanen yang dapat menunjukkan perimbangan antara modal asing dengan modal sendiri (saham 
preferen dan saham biasa) yang digunakan untuk merencanakan mendapatkan modal.

\section{Pendekatan Teori Struktur Modal}

a. Teori Tradisional

"Pendekatan tradisional berpendapat akan adanya struktur modal yang optimal" (Hanafi, 2013:297). Dengan kata lain, struktur modal berpengaruh terhadap nilai perusahaan. Dengan mengubah - ubah struktur modal maka dapat diperoleh nilai perusahaan yang optimal. Penggunaan utang yang terlalu tinggi dapat mengakibatkan nilai perusahaan menurun. Penggunaan utang bisa mempengaruhi nilai perusahaan, yang berarti ada struktur modal yang optimal.

b. Teori Modigliani-Miller (MM)

Pendekatan MM ini bertolak belakang dengan pendekatan tradisional. Pendekatan ini beranggapan bahwa struktur modal tidak mempengaruhi nilai perusahaan. Hanafi (2013:299) menyimpulkan "nilai perusahaan dengan utang lebih tinggi dibandingkan nilai perusahaan tanpa utang".

c. Teori Trade off

Ambarwati (2010:50) menyebutkan bahwa, "Disebut model trade off karena struktur modal optimum terjadi jika terdapat keseimbangan antara biaya financial distress dan agency problem dan manfaat atas penggunaan hutang". Dalam kenyataan, ada hal-hal yang membuat perusahaan tidak bisa menggunakan hutang sebanyakbanyaknya. Satu hal yang terpenting adalah dengan semakin tingginya hutang, akan semakin tinggi kemungkinan (probabilitas) kebangkrutan.

\section{d. Pecking Order Theory}

Secara spesifik, Hanafi (2013:313) menyatakan bahwa "perusahaan mempunyai urutan-urutan preferensi dalam penggunaan dana". Secara ringkas skenario urutan dalam Pecking Order Theory adalah sebagai berikut:

1) Perusahaan memilih internal financing (pendanaan dari hasil operasi perusahaan).

2) Perusahaan menyesuaikan rasio pembagian dividen yang ditargetkan, dengan berusaha menghindari perubahan pembayaran dividen secara drastis.

3) Kebijakan dividen yang relatif segan untuk diubah, disertai dengan fluktuasi profitabilitas dan kesempatan investasi yang tidak bisa diduga, mengakibatkan bahwa dana hasil operasi kadang-kadang melebihi kebutuhan dana untuk investasi, meskipun pada kesempatan yang lain, mungkin kurang. Apabila dana hasil operasi kurang dari kebutuhan investasi (capital expenditure), maka perusahaan akan mengurangi saldo kas atau menjual sekuritas yang dimiliki.

4) Apabila pendanaan dari luar (external financing) diperlukan, maka perusahaan akan menerbitkan sekuritas yang paling aman terlebih dahulu. Yaitu dimulai dengan penerbitan obligasi, kemudian diikuti oleh sekuritas yang berkarakteristik opsi (seperti obligasi konversi), baru akhirnya apabila masih belum mencukupi, saham baru diterbitkan.

e. Teori Asimetri Informasi dan Signaling Konsep signaling dan asimetri informasi berkaitan erat. Teori asimetri mengatakan bahwa pihak - pihak yang berkaitan dengan perusahaan tidak mempunyai informasi yang sama mengenai prospek dan risiko perusahaan. Pihak tertentu mempunyai informasi yang lebih baik dibandingkan dengan pihak lain. Dalam hal ini manajer biasanya memiliki informasi yang lebih baik (mengenai prospek, resiko dan nilai perusahaan) dibandingkan dengan pihak luar (investor) karena merekalah yang mengambil keputusan-keputusan keuangan, yang menyusun berbagai rencana perusahaan, dan sebagainya. Karena itu bisa dikatakan terjadi asimetri informasi antara manajer dengan investor. Investor akan berusaha menginterpretasikan perilaku manajer karena investor merasa memiliki informasi yang lebih sedikit. Dengan kata lain, perilaku manajer termasuk dalam hal yang menentukan struktur modal, bisa dianggap sebagai signal oleh pihak luar (investor).

\section{Debt To Equity Ratio (DER)}

Menurut Munawir (2008:245) "DER adalah rasio antara total utang dengan total modal (share holder's equity) yang memberikan indikasi tentang seberapa jauh kreditor terlindungi jika terjadi insolvensi". Sedangkan Debt To Equity Ratio menurut Sawir (2005:13) "merupakan rasio yang menggambarkan hutang dan modal dalam pendanaan perusahaan dan menunjukkan 
kemampuan modal sendiri perusahaan tersebut untuk memenuhi kewajibannya".

Semakin kecil rasio ini semakin baik perusahaan, sebaliknya, semakin besar rasio ini maka semakin buruk perusahaan karena resiko perusahaan semakin besar. Rumus untuk menghitung DER adalah:

Debt To Equity Ratio (DER)

$$
=\frac{\text { Total Utang }}{\text { Modal (Equity) }}
$$

Harahap (2008:303)

\section{Faktor-Faktor yang Mempengaruhi Stuktur Modal}

Riyanto (2010:296) menyatakan bahwa faktor-faktor yang mempengaruhi struktur modal diantaranya:

a. Tingkat bunga,

b. Stabilitas dari earning,

c. Struktur aktiva,

d. Kadar resiko dari aktiva,

e. Besarnya jumlah modal yang dibutuhkan,

f. Keadaan pasar modal,

g. Sifat manajemen,

h. Besarnya suatu perusahaan,

i. Profitabilitas, dan

j. Pajak.

Sedangkan menurut Brigham dan Houston (2001:39) menyatakan bahwa faktor-faktor yang mempunyai pengaruh terhadap struktur modal adalah :

a. Stabilitas penjualan,

b. Struktur aktiva,

c. Leverage keuangan,

d. Tingkat pertumbuhan,

e. Profitabilitas,

f. Pajak,

g. Pengendalian,

h. Sifat manajemen,

i. Sikap pemberi pinjaman dan lembaga penilai peringkat,

j. Keadaan pasar modal,

k. Kondisi internal perusahaan, dan

I. Fleksibilitas perusahaan.

\section{METODE}

Jenis penelitian ini adalah penelitian deskriptif verifikatif dengan pendekatan kuantitatif. Adapun teknik dalam pengumpulan data dalam penelitian ini menggunakan metode dokumentasi terhadap data sekunder, yaitu berupa laporan keuangan yang diperoleh dari situs resmi Bursa Efek Indonesia.
Populasi dari penelitian ini adalah 16 Perusahaan Manufaktur Subsektor Logam dan Sejenisnya yang terdaftar di Bursa Efek Indonesia periode 2011-2013. Teknik pengambilan sampel menggunakan purposive sampling. Dengan demikian, maka yang menjadi sampel dalam penelitian ini adalah 10 Perusahaan Manufaktur Subsektor Logam dan Sejenisnya yang terdaftar di Bursa Efek Indonesia periode 2011-2013

Dalam penelitian ini, analisis yang digunakan adalah analisis regresi linier sederhana dengan pengujian keberartian regresi (uji F) dan pengujian keberartian koefisien regresi (uji t).

Adapun hipotesis yang dirumuskan dalam pengujian keberartian regresi dalam penelitian ini adalah:

$H_{0}$ : regresi tidak berarti

$H_{1}$ : regresi berarti

Hipotesis yang dirumuskan dalam pengujian keberartian koefisien regresi adalah:

$H_{0}: \beta \geq 0$, Profitabilitas tidak berpengaruh terhadap struktur modal

$H_{1}: \beta<0$, Profitabilitas berpengaruh negatif terhadap struktur modal

Debt To Equity Ratio (DER)

$$
=\frac{\text { Total Utang }}{\text { Modal (Equity) }}
$$

Harahap (2008:303)

\section{HASIL DAN PEMBAHASAN}

\section{Gambaran Obyek Penelitian}

Obyek dalam penelitian ini adalah Perusahaan Manufaktur Subsektor Logam dan Sejenisnya yang terdaftar di Bursa Efek Indonesia periode 2011-2013. Jumlah Perusahaan yang dijadikan sampel pada periode tersebut sebanyak 10 perusahaan.

\section{Gambaran Variabel Penelitian \\ Profitabilitas}

Berikut merupakan ROA Perusahaan

Manufaktur Subsektor Logam dan Sejenisnya yang terdaftar di Bursa Efek Indonesia periode 2011-2013:

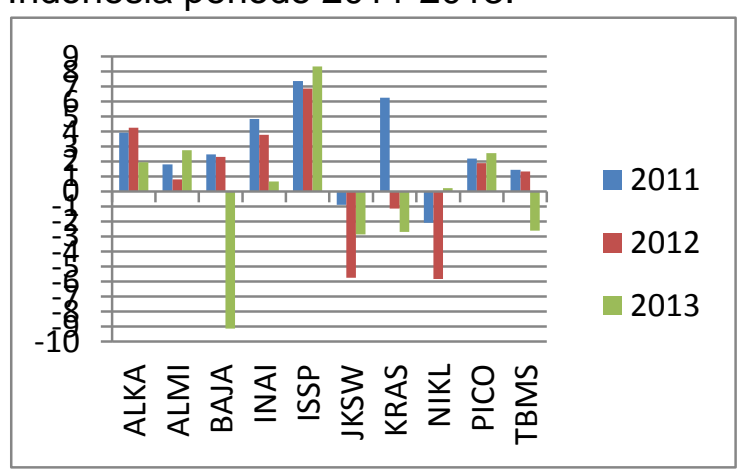




\section{Gambar 2.1 \\ ROA Perusahaan Logam dan Sejenisnya periode 2011-2013:}

Dari Gambar 2.1 dapat dilihat bahwa pada tahun 2011 PT. Pelat Timah Nusantara Tbk memiliki nilai ROA terendah yaitu $-2,09 \%$, sedangkan nilai ROA tertinggi diperoleh PT. Steel Pipe Industry of Indonesia Tbk yaitu sebesar 7,35\%. Pada tahun 2012 PT. Pelat Timah Nusantara Tbk kembali menempati posisi terendah yaitu $5,85 \%$ dan PT. Steel Pipe Industry of Indonesia Tbk kembali memperoleh ROA tertinggi yaitu $6,85 \%$. Selanjutnya di tahun 2013 PT. Saranacentral Bajatama Tbk memiliki nilai ROA terendah yaitu $-9,15 \%$, sedangkan PT. Steel Pipe Industry of Indonesia Tbk tetap menempati nilai ROA tertinggi yaitu sebesar $8,34 \%$.

Jika dilihat dari perubahannya, PT. Alakasa Industrindo Tbk mengalami kenaikan di tahun 2012 namun kembali turun di tahun 2013. PT. Alumindo Light Metal Industry Tbk, PT. Steel Pipe Industry of Indonesia Tbk, PT. Jakarta Kyoei Steel Works Tbk, PT. Pelat Timah Nusantara Tbk dan PT. Pelangi Indah Canindo Tbk mengalami penurunan di tahun 2012 namun berhasil meningkatkan ROA di tahun 2013. Sedangkan PT. Saranacentral Bajatama Tbk, PT. Indal Aluminium Industry Tbk, PT. Krakatau Steel (Persero) Tbk dan PT. Tembaga Mulia Semanan Tbk mengalami penurunan ROA setiap tahunnya.

\section{Struktur Modal}

Berikut merupakan DER Perusahaan Manufaktur Subsektor Logam dan Sejenisnya yang terdaftar di Bursa Efek Indonesia periode 2011-2013:

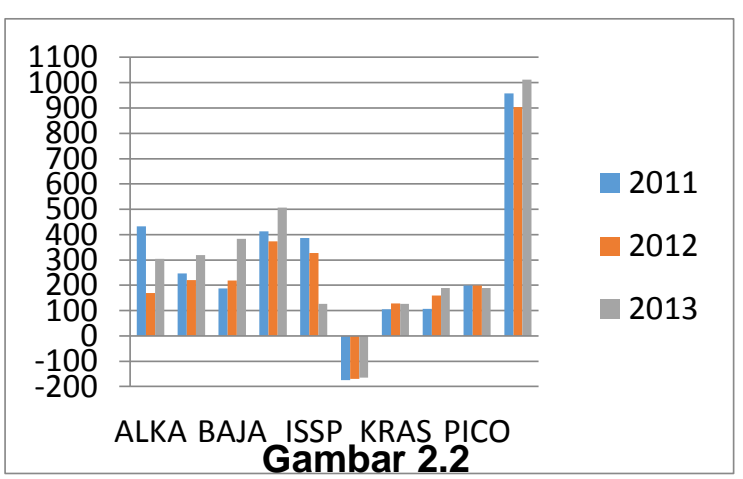

DER Perusahaan Logam dan Sejenisnya periode 2011-2013:

Dari Gambar 2.2 dapat dilihat bahwa PT. Tembaga Mulia Semanan Tbk memiliki nilai DER tertinggi setiap tahunnya yaitu secara berturut-turut 957\%; 904\% dan 1012\%. Berbanding terbalik dengan PT. Tembaga Mulia Semanan Tbk, PT. Krakatau Steel (Persero) Tbk memiliki nilai DER terendah setiap tahunnya yaitu secara berturut-turut 105\%; $129 \%$ dan 126\%. Meskipun nilai DER masih melebihi $100 \%$, namun PT. Krakatau Steel (Persero) Tbk memiliki struktur modal yang lebih baik dibandingkan perusahaan lainnya di lihat dari DER perusahaan.

Jika dilihat dari perubahannya, PT. Alakasa Industrindo Tbk, PT. Alumindo Light Metal Industry Tbk, PT. Indal Aluminium Industry Tbk dan PT. Tembaga Mulia Semanan Tbk berhasil menurunkan nilai DER di tahun 2012 namun DER kembali naik di tahun 2013. Berbeda dengan PT. Krakatau Steel (Persero) yang mengalami kenaikan nilai DER di tahun 2012 namun berhasil turun kembali di tahun 2013 walaupun penurunannya kecil. PT. Steel Pipe Industry of Indonesia Tbk dan PT. Pelangi Indah Canindo Tbk mengalami perubahan yang baik karena berhasil menurunkan nilai DER setiap tahunnya. Sedangkan PT. Saranacentral Bajatama Tbk dan PT. Pelat Timah Nusantara Tbk masih harus memperbaiki struktur permodalan perusahaannya karena nilai DER terus mengalami kenaikan setiap tahunnya. Pada PT. Jakarta Kyoei Steel Works Tbk menunjukkan DER yang negatif dikarenakan perusahaan mengalami defisiensi modal dimana perusahaan mengalami kerugian yang berakibat menurunnya saldo laba ditahan.

\section{Hasil Penelitian \\ Uji Normalitas}

Pengujian ini bertujuan untuk mengetahui data berdistribusi normal.

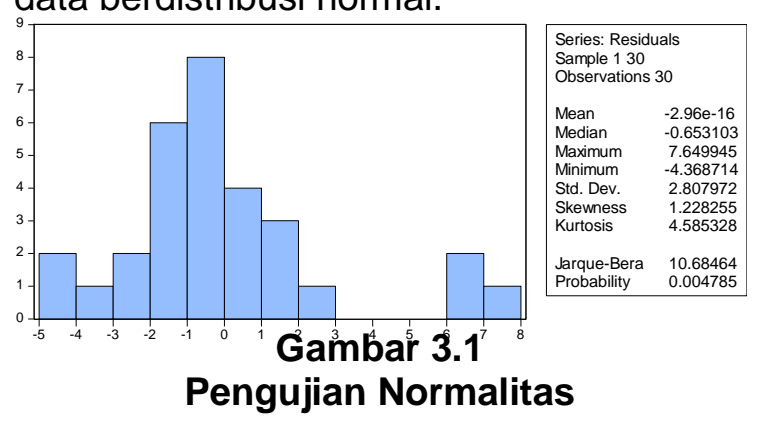

Dari gambar 3.1 diatas dapat dilihat bahwa bentuk histogram menyerupai distribusi normal sehingga dapat disimpulkan bahwa data penelitian ini berdistribusi normal

\section{Uji Linieritas}


Uji linieritas dilakukan dengan tujuan untuk membuktikan bahwa antara variabel $X$ dengan variabel $Y$ memiliki hubungan yang linier.

Tabel 3.1

Tabel Pengujian Linieritas, Regresi Linier Sederhana, Uji F dan Uji t

\begin{tabular}{lrlll}
$\begin{array}{l}\text { DependentVariable:DER } \\
\text { Method: LeastSquares } \\
\text { Date: 05/29/15 Time: 19:06 } \\
\text { Sample: } 130 \\
\text { Included observations: } 30\end{array}$ & & & & \\
\hline \multicolumn{1}{c}{ Variable } & Coefficient & Std. Error & t-Statistic & Prob. \\
\hline \hline \multicolumn{1}{c}{ C } & 1.976241 & 0.511651 & 4.636798 & 0.0000 \\
\multicolumn{1}{c}{ ROA } & 0.017543 & 0.195821 & 0.419733 & 0.0052 \\
\hline \hline R-squared & 0.240673 & Mean dependentvar & 1.997130 \\
Adjusted R-squared & -2.094575 & S.D. dependentvar & 2.000186 \\
S.E. of regression & 3.178639 & Akaike info criterion & 4.212914 \\
Sum squared resid & 438.7272 & Schwarz criterion & 4.299963 \\
Log likelihood & -90.84912 & Hannan-Quinn criter. & 4.252129 \\
F-statistic & 10.61623 & Durbin-Watson stat & 1.577383 \\
Prob(F-statistic) & 0.005239 & & & \\
\hline \hline
\end{tabular}

Dilihat dari tabel 3.1 tersebut dapat dilihat bahwa nilai Durbin Watson (DW) hitung adalah sebesar 1,577383. Jika dibandingkan dengan nilai $\mathrm{dL}(1,2837)$, maka dapat dilihat bahwa nilai DW lebih besar dari pada nilai $\mathrm{dL}(\mathrm{DW}>\mathrm{dL})$. Dari hasil tersebut dapat disimpulkan bahwa data berbentuk linear. Dari hasil tersebut dapat disimpulkan bahwa data berbentuk linear.

\section{Regresi Linier Sederhana}

Analisis regresi linier sederhana dimaksudkan untuk melihat pengaruh profitabilitas terhadap struktur modal.

Berdasarkan tabel 3.1 dapat diperoleh persamaan regresi antara profitabilitas (ROA) dengan struktur modal (DER) sebagai berikut:

$\hat{Y}=a+b X$

$\hat{Y}=1.976241+0.017543 X$

Hasil tersebut dapat disimpulkan bahwa:

a. Konstanta 1.976241 nilai ini menunjukkan jika profitabilitas tidak mengalami perubahan, maka struktur modal memiliki nilai konstanta sebesar 1.976241

b. Jika dilihat arah hubungan, maka menggambarkan arah yang positif atau menunjukan hubungan positif. Artinya peningkatan profitabilitas diikuti dengan peningkatan struktur modal dan begitu juga sebaliknya.

c. Koefisien regresi 0.017543 , nilai ini berarti bahwa setiap kenaikan rasio profitabilitas sebesar $1,00 \%$ maka akan menyebabkan kenaikan nilai struktur modal 0.017543 kali.

\section{Uji F}

Uji F digunakan untuk menentukan apakah variabel independen secara bersama-sama atau simultan berpengaruh terhadap variabel dependen. Rumusan hipotesis dalam uji $\mathrm{F}$ ini dinyatakan sebagai berikut:

$H_{0}$ : regresi tidak berarti

$H_{1}$ : regresi berarti

Dengan kriteria penerimaan dan penolakan sebagai berikut:

Jika nilai $F_{\text {hitung }}>$ nilai $F_{\text {tabel, }}$, maka $\mathrm{H}_{0}$ ditolak dan $\mathrm{H}_{1}$ diterima

Jika nilai $F_{\text {hitung }} \leq$ nilai $F_{\text {tabel, }}$ maka $\mathrm{H}_{0}$ diterima dan $\mathrm{H}_{1}$ ditolak

Berdasarkan perhitungan dengan Eviews 7 diperoleh data pada tabel 3.1 bahwa nilai $F_{\text {hitung sebesar } 10.61623}$ dan $F_{\text {tabel }}$ sebesar 4,20, maka dapat diketahui bahwa $10.61623>4,20\left(F_{\text {hitung }}>F_{\text {tabel }}\right)$ sehingga $\mathrm{H}_{0}$ ditolak dan $\mathrm{H}_{1}$ diterima. Dengan demikian dapat ditarik kesimpulan bahwa regresi berarti.

\section{Uji t}

Uji $t$ dilakukan dengan membandingkan $t$ hitung dengan $t$ tabel. Uji $t$ dilakukan untuk mengetahui keberartian koefisien regresi. Hipotesis dalam penelitian ini berkaitan dengan ada tidaknya pengaruh antara variabel independen yaitu profitabilitas (ROA) dengan variabel dependen yaitu struktur modal (DER). Taraf signifikansinya sebesar 0,05 dan df $30-2=28(n-k)$. Hipotesisnya adalah sebagai berikut:

$H_{0}: \beta \geq 0$, Profitabilitas tidak berpengaruh terhadap struktur modal

$H_{1}: \beta<0$, Profitabilitas berpengaruh negatif terhadap struktur modal

Kriteria pengujian hipotesis yang diajukan adalah sebagai berikut:

Jika nilai $t_{\text {hitung }}<\mathrm{t}_{\text {tabel}}$, maka $\mathrm{H}_{\mathrm{o}}$ diterima dan $\mathrm{H}_{\mathrm{a}}$ ditolak

Jika nilai $t_{\text {hitung }}>t_{\text {tabel}}$, maka $\mathrm{H}_{\mathrm{o}}$ ditolak dan $\mathrm{H}_{\mathrm{a}}$ diterima

Berdasarkan tabel 3.1 dapat dilihat besarnya $t$ hitung adalah sebesar 0.419733 dan besarnya $t_{\text {tabel }}$ adalah sebesar 1.70113. Maka $t_{\text {hitung }}<\mathrm{t}_{\text {tabel, }}$ dengan nilai $0.419733<$ 1.70113. Sehingga $H_{0}$ diterima artinya Profitabilitas tidak berpengaruh terhadap struktur modal.

\section{Pembahasan}

Penelitian ini bertujuan untuk menganalisis dan membuktikan pengaruh profitabiltas terhadap struktur modal pada 
Perusahaan Logam dan Sejenisnya yang terdaftar di Bursa Efek Indonesia. Sebelumnya peneliti telah mengumpulkan data-data sekunder yang berasal dari laporan keuangan perusahaan, laporan tahunan perusahaan, dan dokumendokumen perusahaan yang terkait dengan penelitian. Setelah itu peneliti mengolah data yang sudah dikumpulkan dan menganalisisnya serta melakukan uji hipotesis.

Sebelumnya telah ditampilkan pada gambar 2.1 dapat dilihat bahwa PT. Alakasa Industrindo Tbk mengalami kenaikan di tahun 2012 namun kembali turun di tahun 2013. PT. Alumindo Light Metal Industry Tbk, PT. Steel Pipe Industry of Indonesia Tbk, PT. Jakarta Kyoei Steel Works Tbk, PT. Pelat Timah Nusantara Tbk dan PT. Pelangi Indah Canindo Tbk mengalami penurunan di tahun 2012 namun berhasil meningkatkan ROA di tahun 2013. Sedangkan PT. Saranacentral Bajatama Tbk, PT. Indal Aluminium Industry Tbk, PT. Krakatau Steel (Persero) Tbk dan PT. Tembaga Mulia Semanan Tbk mengalami penurunan ROA setiap tahunnya.

Kemudian rata-rata nilai ROA dari 2,73\% di tahun 2011 mengalami penurunan sebesar $1,84 \%$ di tahun 2012, lalu mengalami penurunan kembali sebesar $1,7 \%$ di tahun 2013. Hal ini menandakan bahwa perusahaan memiliki tingkat profitabilitas yang cenderung menurun.

Bila ingin meningkatkan tingkat profitabilitas perusahaan, perusahaan harus dapat memaksimalkan seluruh kekayaan yang dimilikinya untuk aktivitas operasi agar menghasilkan keuntungan yang setinggi-tingginya. Karena hal ini dapat menghindarkan perusahaan dari penggunaan utang. Perusahaan yang dapat memaksimalkan laba, cenderung menggunakan modal sendiri untuk aktivitas perusahaan karena modal sendirinya mencukupi untuk aktivitas perusahaan. Hal ini menunjukkan perusahaan berhasil menciptakan dana yang aman dan meningkatkan kesejahteraan perusahaan tersebut.

Sementara itu, jika melihat nilai struktur modal Perusahaan Logam dan Sejenisnya yang diukur dengan DER maka dapat dikategorikan kurang baik. Jika melihat gambar 2.2 dapat dilihat bahwa nilai rata-rata struktur modal mengalami kenaikan sampai di angka $299 \%$ pada tahun 2013. Nilai DER tersebut menunjukkan angka yang melebihi standar struktur modal yang optimal. Karena standar struktur modal yang optimal menunjukkan nilai DER $<100 \%$ atau DER tidak boleh melebihi $100 \%$. Dengan kata lain, perbandingan utang harus lebih sedikit dibandingkan modal sendiri perusahaan.

Selanjutnya untuk mengetahui pengaruh profitabilitas terhadap struktur modal perusahaan, maka dilakukan sebuah studi empiris. Analisis uji ini menggunakan regresi linier sederhana dengan alat bantu statistik yaitu EViews 7. Dari hasil uji regresi linier sederhana menunjukkan bahwa profitabilitas mempunyai pengaruh yang positif terhadap struktur modal. Setiap kenaikan rasio profitabilitas sebesar 1,00\% maka akan menyebabkan kenaikan nilai struktur modal 0.017543 kali. Selanjutnya dalam penelitian ini dilakukan juga uji keberartian regresi yang menggunakan uji $\mathrm{F}$ didapatkan hasil bahwa variabel independen profitabilitas memiliki keberartian terhadap variabel dependen yaitu struktur modal. Kemudian selain menggunakan uji $\mathrm{F}$ sebagai uji keberartian regresi, penelitian juga melakukan pengujian keberartian koefisien regresi melalui uji t. Setelah melakukan uji t untuk melihat pengaruhnya, didapatkan hasil bahwa variabel profitabilitas tidak berpengaruh terhadap struktur modal. Dapat disimpulkan bahwa profitabilitas tidak berpengaruh terhadap struktur modal. Dalam kenyataannya, pada perusahaan Logam dan Sejenisnya, perusahaan dengan tingkat profitabilitas yang baik mempunyai utang yang cukup tinggi. Dengan kata lain, profitabilitas tidak menurunkan nilai struktur modal. Perusahaan dengan utang yang besar dibandingkan dengan modal dikatakan memiliki struktur modal yang kurang optimal, tetapi pada perusahaan Logam dan Sejenisnya, utang-utang perusahaan bukan merupakan utang yang berbahaya seperti pembayaran bunga, denda, utang bank dan utang obligasi melainkan utang yang mendukung perusahaan untuk berkembang. Sehingga kenaikan profitabilitas dapat diikuti dengan kenaikan struktur modal.

Perusahaan dengan profitabilitas yang tinggi memberikan signal dengan memakai utang yang lebih besar lagi. Hal ini sesuai dengan Signaling Theory yaitu "perilaku manajer termasuk dalam hal yang menentukan struktur modal, bisa dianggap sebagai signal oleh pihak luar (investor)".

Pada penelitian ini, perusahaan Logam dan Sejenisnya yang memiliki 
profitabilitas yang baik mempunyai utang yang cukup banyak. Utang tersebut bukan merupakan utang yang berbahaya melainkan digunakan perusahaan untuk kegiatan operasi agar aktivitas operasi perusahaan berjalan lancar. Keputusan perusahaan Logam dan Sejenisnya untuk menggunakan utang dikarenakan perusahaan membutuhkan dana yang besar untuk pengembangan operasinya, dan jumlah modal sendiri perusahaan tidak mencukupi untuk membiayai keseluruhan aktifitas operasi, oleh karena itu perusahaan menggunakan utang. Dengan kata lain, perusahaan memilih menggunakan utang karena utang lebih menguntungkan dibandingkan dengan menggunakan modal sendiri, selain itu jumlah modal sendiri tidak mencukupi untuk membiayai kebutuhan dana perusahaan yang sangat besar. Dalam packing order theory pun dikatan bahwa perusahaan akan menggunakan pendanaan dari luar (eksternal financing) apabila dana itu memang diperlukan.

$\begin{array}{ccr}\text { Utang } & \text { yang } & \text { tinggi dapat } \\ \text { memperbesar } & \text { risiko } & \text { perusahaan }\end{array}$ mengalami kebangkrutan, akan tetapi selama tingkat penggunaan utang tersebut belum mencapai tingkat leverage tertinggi maka penggunaan utang masih aman. Dalam hal ini, perusahaan tetap memperhatikan penggunaan utangnya sampai batas maksimum penggunaan utangnya. Dari pemaparan-pemaparan tersebut, dapat disimpulkan bahwa tingkat profitabilitas perusahaan tidak mempunyai pengaruh terhadap struktur modal.

Sesuai dengan penelitian Gurmeet Singh H (2014) yang berjudul "Interrelation Between Capital Structure and Profitability of FMCG Companies of India". Hasil penelitiannya adalah profitabilitas perusahaan dan leverage keuangan memiliki dampak tidak signifikan terhadap struktur modal dari perusahaanperusahaan yang diteliti selama periode diperiksa. Oleh karena itu, dalam penelitian ini tidak terdapat pengaruh antara profitabilitas dan leverage keuangan terhadap struktur modal dari suatu perusahaan. Penelitian yang dilakukan Ginanjar Indra Kusuma, Suhadak, Zainul Arifin (2012) yang berjudul "Analisis Pengaruh Profitabilitas dan Tingkat Pertumbuhan terhadap Struktur Modal dan Nilai Perusahaan pada Perusahaan Real Estate yang Terdaftar di Bursa Efek Indonesia (BEI) Periode 2007-2011". Hasil penelitiannya menunjukkan variabel profitabilitas berpengaruh tidak signifikan terhadap struktur modal. Dengan demikian, berdasarkan penelitian terdahulu, variabel profitabilitas tidak mempunyai pengaruh terhadap struktur modal.

\section{KESIMPULAN}

Berdasarkan hasil dari pembahasan dan penelitian telah dilakukan maka dapat ditarik kesimpulan sebagai berikut:

1. Profitabilitas perusahaan Logam dan Sejenisnya selama periode 2011-2013 yang diukur dengan Return On Assets (ROA) memiliki rata-rata yang terus menurun.

2. Struktur modal perusahaan Logam dan Sejenisnya selama periode 2011-2013 yang diukur dengan Debt Equity Ratio (DER) memiliki rata-rata yang fluktuatif dan cenderung naik.

3. Hasil penelitian pengaruh profitabilitas terhadap struktur modal pada Perusahaan Manufaktur subsektor Logam dan Sejenisnya yang terdaftar di BEl menunjukkan bahwa tidak terdapat pengaruh profitabilitas terhadap struktur modal. Pada kenyataannya, perusahaan masih dapat menghasilkan keuntungan dengan menggunakan utang. Dengan demikian, hipotesis yang peneliti ajukan ditolak karena hasil penelitian tidak sesuai dengan hipotesis awal yang diajukan peneliti yaitu profitabilitas berpengaruh negatif terhadap struktur modal.

\section{SARAN}

1. Perusahaan diharapkan dapat meningkatkan profitabilitas agar perusahaan dapat mempertahankan kelangsungan hidupnya. Salah satu cara untuk meningkatkan profitabilitas perusahaan yaitu dengan mengefektifkan pengelolaan aktiva yang dimiliki perusahaan agar dapat menghasilkan keuntungan.

2. Perusahaan harus dapat mengelola penggunaan hutang secara efisien. Jika perusahaan mampu mengoptimal nilai DER maka perusahaan dapat meminimumkan biaya modal. Ataupun dengan mengefisienkan jumlah hutang yang dapat dijamin oleh modal yang memadai dengan cara memilih jenis hutang yang mempunyai risiko kecil.

3. Bagi para peneliti selanjutnya yang tertarik untuk meneliti pengaruh profitabilitas terhadap struktur modal perusahaan, dapat mencari referensi mengenai faktor-faktor yang 
mempengaruhi struktur modal. Selain itu, disarankan pula untuk meneliti faktorfaktor lainnya yang mempengaruhi struktur modal seperti stabilitas penjualan, struktur aktiva, keadaan pasar modal, sifat manajemen, pajak dan sebagainya.

\section{DAFTAR PUSTAKA}

\section{Sumber Buku:}

Ambarwati, S.D.A. (2010). Manajemen Keuangan Lanjutan. Yogyakarta:Graha IImu.

Brigham, F.E., and Joel, F.H. (2001). Manajemen Keuangan. Jakarta:Erlangga

Hanafi, M.M. (2013). Manajemen Keuangan. Yogyakarta:BPFE.

Harahap, S.S. (2008). Analisis Kritis Atas Laporan Keuangan. Jakarta:PT. Rajagrafindo.

Harmono. (2011). Manajemen Keuangan Berbasis Balanced Scorecard Pendekatan Teori, Kasus, dan Riset Bisnis. Jakarta:Bumi Aksara.

Horne, J.C., and John, M.W. (2007). Prinsip-Prinsip Manajemen Keuangan. Jakarta:Selemba Empat.

Irawati, S. (2005). Manajemen Keuangan. Bandung:Pustaka.

Munawir. (2008). Analisis Informasi Keuangan. Yogyakarta:Liberty.

Riyanto, B. (2010). Dasar-dasar Pembelajaran Perusahaan. Yogyakarta:BPFE.

Sartono, A.(2008). Manajemen Keuangan (Teori dan Aplikasi). Yogyakarta:BPFE

Sawir. A. (2005). Analisis Kinerja Keuangan dan Perencanaan Keuangan Perusahaan. Jakarta:PT. Gramedia Pustaka Utama.

Sutrisno. (2005). Manajemen Keuangan. Yogyakarta:Ekonisia.

$$
\text { (2009). Manajemen Keuangan }
$$

Teori, Konsep, dan Aplikasi.
Jakarta:Ekonisia.

\section{Sumber Jurnal:}

Gurmeet, S.H. (2014). Interrelation Between Capital Structure and Profitability of FMCG Companies of India. International Journal of Accounting and Financial Management Research (IJAFMR).

Kusuma, G.I, Suhadak, dan Arifin, Z. (2012). Analisis Pengaruh Profitabilitas dan Tingkat Pertumbuhan terhadap Struktur Modal dan Nilai Perusahaan pada Perusahaan Real Estate yang Terdaftar di Bursa Efek Indonesia (BEI) Periode 20072011. Fakultas IImu Administrasi Universitas Brawijaya Malang.

\section{Sumber Internet:}

Indonesia Stock Exchange. [Online]. Tersedia: http://www.idx.co.id 